\title{
The Politics of the Environment in Australia
}

Kate Crowley

The Oxford Handbook of Australian Politics

Edited by Jenny M. Lewis and Anne Tiernan

Subject: Political Science, Regional Studies Online Publication Date: Dec 2020

DOI: $10.1093 /$ oxfordhb/9780198805465.013.16

\section{Abstract and Keywords}

Australia has a distinctive environment, with rich remnant biodiversity, mega-diversity (Kirkpatrick 1994), and World Heritage listings, but it persists with Eurocentric settler practices, exploiting its natural resources, and rolling back its ecological frontiers. Valuing nature and transitioning to sustainability are advocated by experts, academics, green political parties, environmental NGOs, and, increasingly, by civil society. However, attention to environmental policy waxes and wanes according to national circumstances, with the major parties typically more accommodating of pressures to develop than protect the environment. Ecology and climate change are therefore persistent challenges that are routinely subject to political contestation and polarization. While recurrent developmentalism, environmental impacts and policy failures are central to Australian politics today, they are not prominent in political or policy-based analysis. This chapter presents an overview of the key issues.

Keywords: Australian environment, environmental exploitation, environmental protection, environmental policy, statist developmentalism

Australia is roughly equivalent in size to the United States and roughly double the size of Europe, stretching from the tropics to the sub-Antarctic and from the Pacific Ocean to the Indian Ocean. However, this vastness belies the continent's ecological fragility. The interior is desert, surrounded by semi-desert, leaving 90 per cent of the country barely inhabited and the population of twenty-five million living predominantly near the coast. Somewhat incongruously, this vast nation has 'one of the most urbanised and coast-dwelling populations' (Australian Government 2018) in the world, which impacts on its cities and regional environments. Arable land is scarce, and Australia suffers from record rates of land clearing (Preece and Oosterzee 2017); indeed, since European settlement it has had the highest rates of ecosystem destruction in the world (Lines 1991). There are nevertheless more than two dozen iconic natural areas protected as World Heritage Sites, including Kakadu National Park, the Great Barrier Reef, and much of the Tasmanian wilderness. 


\section{The Politics of the Environment in Australia}

Australia fares poorly on most environmental scorecards. It recently ranked third last for environmental policy performance out of the twenty-seven most developed countries, most notably for its policy failure on climate change (Hunter 2018). It is consistently among the highest per capita greenhouse gas emitters and has been identified as the worst-performing country in the world on climate action. ${ }^{1}$ Of the 188 countries with populations of more than one million, Australia consistently ranks among the world's highest in terms of ecological footprint per capita. Consistent with its record rates of land clearing, and as the only developed country listed in the top ten land-clearing nations in the world, over the last fifty years Australia's biocapacity (the capacity of natural ecosystems to regenerate) has halved (GFN 2018). These poor assessments are routine, and yet attract little scholarly attention.

It is not surprising, then, that Australia has a robust environmental politics. For example, the 1972 damming of Lake Pedder in Tasmania's pristine South West Wilderness spawned the world's first Greens party (Rainbow 1993a, 1993b). Neither the Labor nor Liberal parties prevented the Hydro-Electric Commission from damming the lake, despite vigorous campaigning by conservationists. Pedder's loss illustrated that both liberal and conservative governments would sponsor economic development without regard for the ecological cost, betraying an anthropocentric, Lockean view that nature's only value is in its exploitation by humans (Walker 2011). Australia's environmental problems stem from this attitude, and from 'statist developmentalism' in which the state itself is involved in sponsoring development (Walker 1999, 2011). The loss of Lake Pedder, and a resulting 'never again' mentality from conservationists, inspired the development of contemporary environmental politics in Australia.

This chapter explores the settler, frontierist underpinnings of statist developmentalism, the enduring consequences for the state of the Australian environment, the politics of environmental protection, and lessons from environmental policy rollback and failure.

\section{Still Settling the Frontier}

From the beginnings of European settlement, the early colonists were dedicated to rolling back the natural frontier and were assisted in doing so by their home country, the colonial governments, and, from Federation in 1901, the Australian state. This settler society mindset-that the environment is a resource to be exploited-has been referred to as 'quarry Australia' (Birrell, Hill, and Stanley 1982) and is recognizable today (Dovers 2000). Although not widely appreciated, the settler society mindset has also had a 'taming nature' aspect to it, which reflects a fear of terra nullius-the so-called 'empty continent' that Australia had been declared to be in order to justify European occupation (Lines 1991). Of course, it was not empty; for at least 60,000 years, Australia's Indigenous peoples had employed an active 'stewardship' approach to the environment with little discernible ecological impact. European arrival brought industrialized agricultural and environmental practices with a propensity for ecological damage. The environment was 'improved' by clearing the bush, cropping became 'more efficient' with irrigation, and na- 


\section{The Politics of the Environment in Australia}

tive species were substituted with 'more productive' species from home (Walker 2011: 12). Although Aboriginal peoples were already employing less invasive, more sustainable ecological and land management techniques, these were not considered by the burgeoning colonies (Gammage 2012).

In order to underpin the economies of these colonies, their governments focused on investment and nation-building infrastructure development, in a process Noel Butlin (1983) refers to as 'colonial socialism'. However, political ecologist Ken Walker (1999) has critiqued this notion, claiming that there was nothing socialist in the advance of private interests by government that caused enormous ecological damage, often to promote schemes that would otherwise fail. With the rise of environmentalism, the 'quarry Australia' and 'colonial socialism' mindsets began to be challenged by a series of increasingly ecocentric counter-paradigms. The first of these, resource conservation, had its origins in 1960s. It evolved into a paradigm of environmental protection, which was prominent from the 1980s, and which informs approaches to environmental sustainability today (Webb, Whitelock, and Brereton 1969; Powell 1978; Bolton 1992; Smith 1994; Yencken and Wilkinson 2000; Lowe 2005).

Nevertheless, 'quarry Australia' and statist developmentalism are deeply ingrained in the Australian psyche. Most Australians recognize that governments subsidize economic activity to promote development, with industrial and governmental interests at times 'interlocked' (Walker 2011: 13). Government support for the Adani project, the world's largest proposed coal mine, is a classic example of government prioritizing development through infrastructure and political support (Cox 2019; Quiggin 2017; Sengupta, Williams, and Chandrasekhar 2019). Close state-developer relations have had implications for the treatment of environmental issues and the development of environmental policy that are recognizable today, not least of which is the danger of political capture of the state by private interests.

In Environmental Policy Failure: The Australian Story, Crowley and Walker (2012) summarize instances of political capture and of the undermining of environmental stewardship and loss of impartial policy judgement that can result. For example, they cite economist Ross Garnaut, who credits corporate interests with derailing Australia's climate policy and stymieing renewable energy advances (see also Pearse 2007; Readfearn 2018). Crowley and Walker (2012) also examine how developers and agriculturalists have been credited as the major cause of the failure of Murray-Darling Basin water reforms, and of failed attempts more generally to achieve sustainable natural resource management. Furthermore, they look at the failure of coastal and marine policy where it has favoured the oil, gas, and fishing industries and interests to the neglect of scientific and conservation concerns.

Despite the persistent 'quarry Australia' mindset (Mercer and Marden 2006), attitudes towards the environment have evolved from the 'exploitative pioneering' era (1788-1900), during which the Australian colonies were established. Frawley (1994) argues that a 'national development and wise resource use' era (1900-1960s) followed Federation, but 


\section{The Politics of the Environment in Australia}

that the environmental costs of nation-building were questioned in a 'challenge to development' era (1960s-1990s). This led to a significant period of environmental policy development in the 1970s and 1980s, only to be followed by environmental policy rollback beginning in the 1990s. In this era, efforts to prioritize the environment were matched by efforts to deprioritize it, and to devolve responsibility back to the states (Walker and Crowley 1999). Discernible stages of environmental policy development, implementation, and contestation were then followed, as they have been in the United States and Canada, by policy dismantling and decline (discussed later in this chapter).

Today, Australia is still effectively settling its frontier society, pushing back the natural boundaries and exploiting its resources in order to generate growth and export earnings, and clearing its remnant native vegetation at an accelerating rate (Hepburn 2018). It is far from achieving the 'political and cultural change' that would see a more benign Indigenous environmental stewardship and land management ethos adopted (Morton et al. 1995). It is not transitioning to a more sustainable, less carbon-intensive, future-oriented society, and, with no discernible population policy, its cities are suffering from a lack of basic planning and public transportation. Nevertheless, a new generation of sustainability theorists, practitioners, and activists is challenging this environmental neglect, pursuing change, and embarking on environmental justice campaigning and research. ${ }^{2}$

\section{The State of the Environment}

Enduring unease regarding the deteriorating state of the Australian environment, whether expressed by civil society, scientists, farmers, politicians, or analysts, indicates that there is clearly a problem (Mercer and Marden 2006; Lindenmayer 2007; SEAC 2016). Experts are concerned about water health and supply, the failure to reduce greenhouse gas emissions, the failure to transition to renewable energy, reliance on coal for fuel and export revenue, the biodiversity crisis, intensifying drought and bushfire seasons, and the pollution and overfishing of the oceans. They are also concerned about urban population pressures, the lack of smarter sustainable city development and infrastructure, the lack of investment in public transport, and the failure of political leadership (White 2009). These issues are long-standing, and their championing has inspired some improvements, but state-of-the-environment reporting consistently identifies that adequate prioritization and resourcing is lacking, and that policies and programmes are failing (SEAC 1996, 2006, 2016).

It is crucial for scholarly political research to track both the state of the Australian environment and the unfinished politics of environmental protection, while learning lessons from evidence-based research and policy successes and failures. The basis for such lessons can be found in more than twenty years of comprehensive environmental reporting, such as the Australian Environmental-Economic Accounts compiled by the Australian Bureau of Statistics (ABS 2018), which began in 1992; in the State of the Environment Advisory Council's reporting, which began in 1996 (SEAC 1996, 2006, 2016); and, externally, in the OECD's Environmental Performance Review: Australia (OECD 1998, 2008, 


\section{The Politics of the Environment in Australia}

2019). Such reporting produces a range of data and comparative data by which to measure environmental policy progress and effectiveness. However, there are limitations to this data. The research from which it is gathered is undertaken with varying levels of expertise and is impacted by varying levels of political influence. Moreover, it isn't a substitute for issue-based data or research (see, for example, Hoegh-Guldberg 2016; Merlin et al. 2015; Reside et al. 2017), nor for data documented discursively by public reviews and inquiries.

For example, the Australian Senate Standing Committee on Environment and Communications facilitates expert overviews, albeit within politicized environments, which capture the Senate's efforts to scrutinize the environmental policy efforts of federal governments. Since 1988, it has undertaken more than 240 predominantly environment-oriented inquiries that identify a host of specific environmental policy problems and proffer solutions (SSCEC 2018). In addition, since 1995, the Australian National Audit Office has released more than seventy environment-specific reports that provide detailed feedback on the rationale for, and the cost, implementation, and success of, a broad range of environmental policy initiatives (ANAO 2018). Such inquiries offer a wealth of research data but are not the focus of political or policy analysis.

Both the OECD (2019) Environmental Performance Review of Australia and the most recent State of the Environment (SOE) report (SEAC 2016) point to some of the basic policy and procedural reasons for policy failure, albeit without tackling the political drivers. The consequences of environmental decline across a range of aspects and indicators are identified in the 2016 SOE report, which demonstrates concern about the ongoing failure to implement sustainable management and about the synergistic or cumulative impacts that are becoming more prominent and more threatening. It identifies the key drivers of environmental degradation as population growth and economic activity, and the key pressures on the environment as land clearing, land-use change, habitat fragmentation and degradation, and invasive species. Additional pressures include climate change, altered fire regimes, overuse of species and habitats, ocean acidification, pollution in coastal and marine environments, and the impacts of energy production, mining, and agriculture (SEAC 2016).

Despite these concerns and the wealth of information informing them, effective policy responses have not been forthcoming. It is worth reflecting, as political and policy analysts, on why this may be so, and indeed on why Australian political researchers have thus far paid such scant attention to the details of environmental policy analysis.

\section{The Politics of Protection}

Frontierist attitudes, the settler mindset, and statist developmentalist practices may explain natural resource exploitation, but they do not reflect the major advances in, or the public acceptance of, more protective practices. Conservation and environmental activism have a long history in Australia, particularly in the campaigning for the establishment of national parks and the protection of endemic flora and fauna that began in the 


\section{The Politics of the Environment in Australia}

1890s. Foresters, ecologists, conservationists, philosophical societies, naturalists, and bushwalkers have advocated a protective approach to the environment since the pre-Federation years (Boardman 1990; Bonyhady 1993; Hall 1992). The 1960s were key awareness-raising, agenda-setting years for the environment; this prompted environmental institution-building in the 1970s, which was followed by iconic environmental battles in the 1980s, with some notable wins. Many areas to achieve protection, such as the Franklin River, Tasmania's South West Wilderness, the Great Barrier Reef, and the Wet Tropics of Queensland, were subsequently listed as World Heritage Areas (UNESCO 2018).

Australia has a rich and diverse set of environmental non-government organizations that range from very local groups (with focuses such as land care and restoration) to highly political national bodies, independent research organizations, and think tanks. Activist organizations such as the World Wildlife Fund for Nature (WWF), the Australian Conservation Foundation, the Wilderness Society, Friends of the Earth, and the national, state, and territory-based Greens parties have been campaigning in Australia for decades. They have dedicated significant attention to issues such as land clearing, coal seam gas mining, the promotion of renewable energy, and action on climate change. Furthermore, new generations of urban activists are campaigning for investment in sustainable cities, public transport and cycling infrastructure, waste reduction, reuse and recycling, economic justice, and a transition to nuclear-free and coal-free futures (see FOE 2018).

There may be an exploitative attitude towards nature in Australia, but there is also a willingness to fight for the environment, even if some of the protections achieved are shortlived or inadequate (Bonyhady 1993). Some of the classic environmental battles fought over forests, water, endangered species, and reef protection are being fought all over again by new generations of activists. The battle to protect the Great Barrier Reef, prominent in the 1960s (Wright 1977) and resulting in World Heritage listing in 1981, continues today against the damage from climate change, pollution, mining, and tourism (McLeish 2017). The battle to save Tasmania's forests, which is decades old (Krien 2012) and has seen major wins and losses, continues with conservative government attempts to strip 74,000 hectares of forest of its World Heritage status (Mathieson 2014). The Murray-Darling Basin occupies one-seventh of Australia's land mass and generates 40 per cent of its agricultural production, but has been mismanaged for more than a hundred years (Grafton et al. 2018; Guest 2017). In 2019, a combination of drought, climate change, mismanagement, and politics caused one million fish in the region's river system to die simultaneously in the largest such event in Australia's history (Kilvert 2019).

Australians are overwhelmingly supportive of environmental protection. They feel a strong sense of ownership of their 'big environmental backyard' and have rising concerns about it (WWF 2018). When asked about the natural environment, 82 per cent of all respondents said it is 'declining' or 'getting worse', despite believing it is currently in relatively good health, with 81.3 per cent agreeing that 'if we don't act now we will never control our problems'. While only 51 per cent of respondents between eighteen and twenty four agreed that 'at heart I'm an environmentalist' (compared to 69 per cent of those over sixty-five), 95 per cent of them believe climate change is happening, 49 per cent be- 


\section{The Politics of the Environment in Australia}

lieve we should have more national parks, and 77 per cent recycle or compost as much household waste as possible. Eighty-nine per cent of respondents support protecting the Great Barrier Reef; however fewer support the protection of Queensland's Daintree Rainforest (39 per cent); Tasmania's forests (38 per cent), and Kakadu National Park in the Northern Territory (32 per cent).

Australian elections are rarely dominated by environmental concerns; if they were, the Australian Greens would poll significantly higher than 10 per cent. And the major parties -Labor and the Liberal-National Coalition-would suffer electorally in unprecedented fashion for the flaws and inconsistencies in their environmental policies and practices when in government. However, even with the clamouring for action on climate change during the 2019 election campaign, a climate denialist government was returned (Cave 2019). At the time, the environment and climate change concerned only 26 per cent of voters (and only 50 per cent of Greens voters), and were less important than healthcare, security, the economy, jobs, education, and taxation rates (EMC 2019). Less than a year later, however, the devastating 2019-2020 bushfire season saw thirty-three lives, seventeen million hectares, 3,094 homes, and over a billion native animals lost in frightening circumstances across the country. In the wake of this disaster, indeed as it was still unfolding, 'the environment' leapfrogged 'cost of living', 'healthcare' and 'the economy', jumping ten points in a month to rate as Australians' top concern (Irvine 2020).

This recent heightened concern is yet to translate into bone fide climate change and environmental action from their current conservative government. Indeed, the enthusiasm of the major parties for statist developmentalism and economic rationalism means policy is rarely informed by the public's environmental concerns. Furthermore, neither party has been consistent in their environmental positioning or policies. At times they are complementary, such as when federal Labor established environmental protection legislation in the early 1970s and the conservative Liberal governments did the same in Victoria and Tasmania. At other times, somewhat counter-intuitively, the conservatives have acted as conservation champions, such as when a Tasmanian Labor government tried to flood the Franklin River while the federal Coalition was recommending it for World Heritage listing (a process that was finalized by federal Labor) (Green 1984). And although the Howard Coalition government (1996-2007) refused for over a decade to act on climate change (Crowley 2010), it still introduced the world's first mandatory renewable energy target in 2001, and, in 2007, under intense public pressure, at least proposed a national emissions trading scheme (ETS). Labor governments have been more forthright in pursuing climate action than the conservative Coalition (which is torn between representing its urban and regional constituents), and achieved a short-lived carbon-pricing scheme in 2012 (discussed later in this chapter). However, Labor environmental policy is under consistent pressure due to the party's concern with jobs and appeasing the union movement. In late 2019, for example, as Australia's worst bushfire season was unfolding and residents in his hometown of Sydney were choking on smoke, Labor leader Anthony Albanese toured regional towns in Queensland advocating the jobs and economic benefits of more coal mining (Brown 2019). 


\section{The Politics of the Environment in Australia}

The divide between environment and economy in Australian politics remains clear today, despite some integration of the environment into mainstream concerns (Galvin 2006). Much of the lighter-green environmental agenda, such as recycling and pollution reduction, has been accepted by mainstream society, but deeper battles over natural resources such as water, coal, forests, and uranium remain fierce. At the time of writing, there are proposals to drill for oil and gas in the Great Australian Bight, to prolong ageing coal mines with taxpayer support, to clear huge tracts of native woodland, and to open Queensland up to significantly more coal mining. There is hope that the 'quarry Australia' mindset will lose traction as increasing political activism makes its impacts more apparent. However, the politics of protection has been massively impacted by the efforts of conservative governments in particular to roll back and dismantle environmental policy, and to silence environmentalist dissent within civil society (Hamilton and Maddison 2007; Taylor 2015).

\section{Environmental Policy Rollback and Failure}

The major parties in Australia are relatively united in their pursuit of market-based priorities, their prioritization of growth, and their practice of statist developmentalism. However, tensions exist within the parties over the issue of 'protection or development'. This partially explains the nation's environmental policy inconsistency, rollback, and failure, which can be illustrated in its decades-old history of climate policy and emissions reduction recalcitrance. These tensions were apparent within the Hawke Labor government (1983-1991), which prioritized economically rationalist policy reforms while embarking on environmental protection and environmental institution-building. It established the Resource Assessment Commission (RAC) to inquire into mining, forestry, and coastal issues using a participatory process and evidence-based analysis (Stewart and McColl 1994). However, Hawke's successor, Labor Prime Minister Paul Keating, deprioritized the environment, dismantling the RAC, reversing efforts to reduce emissions, sidelining an ecologically sustainable development process, and devolving environmental responsibility back to the states and territories (Walker and Crowley 1999).

It was these actions of the Keating government that inspired the Howard-led Opposition to woo environmental voters in 1996 by promising the largest environmental policy spend in Australia's history, a Natural Heritage Trust to administer it, and legislation to clarify the environmental powers of the federal government (Crowley 2001). Despite this, and as a further illustration of policy inconsistency, after winning government the Coalition further dismantled environmental policy, withdrew funding from the environmental movement, and refused to ratify the 1997 United Nations Kyoto Protocol to reduce emissions. Such actions affirm Toyne's (1994) view that Australian governments are not only reluctant to protect the environment, but that they will also resist and even roll back protection. This backwards and forwards policy momentum has left environmental politics unsettled in Australia, unnecessarily prolonging the tensions between protection and development (Mercer and Marden 2006). 


\section{The Politics of the Environment in Australia}

The contemporary failure of Australian climate policy has its origins in the inaction of the Hawke and Keating Labor governments, whose willingness to act was readily dampened by vested interests (Hamilton 2001; Pearse 2007; Talberg, Hui, and Loynes 2016). Indeed, Taylor (2014) establishes that industry groups, free market advocates, and climate contrarians reframed early climate change debates in the 1980s from a matter of public interest to one of corporate interest and thwarted action before it was ever taken. Pearse's (2007) interviews with insiders from the Howard Coalition government show how close relations between the government and the fossil fuel industry stifled climate policy action from 1996 until 2007. During the 2007 election campaign, concern peaked over enduring drought, what had then been Australia's worst bushfire season, and a lack of action on climate change (Warhurst 2007). Polling showed that 82 per cent of adults were concerned about the environment, 90 per cent about water shortages, and 73 per cent about climate change (ABS 2009).

Labor Opposition leader Kevin Rudd set the climate policy reform agenda in the lead-up to the 2007 election with promises of substantive action to deal with the 'great moral challenge' of climate change (Rootes 2008). Labor won the election, and ratified the Kyoto Protocol as its first act in office. The Rudd government also proposed an innovative carbon pollution reduction scheme (CPRS), though this was abandoned after political machinations, leadership manoeuvring, and holdout tactics by the Australian Greens resulted in a lack of support in the Senate. The Coalition Opposition was torn between thenleader Malcolm Turnbull's embrace of the CPRS and the scepticism of arch-conservative Tony Abbott, who subsequently deposed Turnbull over the issue. The CPRS had not been green enough for the Greens, who wanted a more abrupt policy change without the level of proposed industry subsidization, exemptions, and transition allowances. As Rudd prevaricated over how to proceed, he was himself deposed by his deputy, Julia Gillard (Crowley 2010).

In 2010, when Labor was returned as a minority government under Gillard, the Greens, who now shared the balance of power in the House of Representatives with a number of independents, made carbon-pricing a condition of their support (Crowley 2013). The Gillard government negotiated the introduction of the Clean Energy Act 2011 and a carbon-pricing initiative that was abolished by the Abbott Coalition government after it won the 2013 election (Crowley 2017). The Abbott government also embarked on widespread environmental policy rollback. It abolished climate change bodies, cut environmental funding and staff, terminated marine parks planning, and permitted the culling of protected great white sharks (Milman 2014). At the time, while the Abbott government was also threatening the protected status of the Great Barrier Reef and World Heritage forests, 91 per cent of Australians rated the protection of the reef as important (including 89 per cent of Coalition voters), and 86 per cent rated the protection of native forests as important (including 83 per cent of Coalition voters) (EMC 2014).

Such environmental policy dismantling has had significant implications, pulling policy consensus to the right and making it hard to restore programmes and funding, and virtually impossible to achieve the pricing of carbon emissions. Australia has been condemned 


\section{The Politics of the Environment in Australia}

by the international community for its failure to instigate effective climate change policies that achieve emissions reductions in line with global aspirations. When Malcolm Turnbull replaced Tony Abbott in a party-room leadership coup in September 2015, there were high hopes for a return to the sensible policy approach of the Gillard government. However, these hopes were misplaced; conservatives within both the Liberal and National parties constrained their new leader's climate policy actions, and eventually deposed Turnbull for attempting to introduce energy policy. Under its new leader, Scott Morrison, the Coalition is persisting with an updated version of the Abbott government's much-criticized voluntary Direct Action climate policy (Readfearn 2018).

\section{Learning from Failure}

Environmental protection and sustainability are unfinished business in Australia. Deep changes are required in attitudes, and governments need to embrace deliberative processes that incorporate public concerns. Much can be learned from Australia's welldocumented environmental decline and the advances that have been made in addressing it. Farming practices have taught us much about ecological vulnerability and limits in terms of the arid nature of the continent, the fragility of its soil, the scarcity of water, and the historical drought-flood patterns (Mercer and Marden 2006). We know that land clearing can be catastrophic, as can siphoning off water from the Murray-Darling Basin and other watersheds for irrigation. We need such lessons to be learned in order to justify clearing controls, smarter agriculture, alternative crops, riparian reconstruction, and offthe-grid sustainability for remote farms. Australia could be a world leader in ecological restoration, and in identifying the social, political, and biophysical components needed to generate ecologically resilient communities, if it were to attend to environmental decline in a manner informed by evidence. But such research lacks profile, impetus, and the political acceptance needed for attracting significant support and lasting institutionalization.

Equally, there are lessons to be learned from the process of colonization (Frawley 1994). The 'exploitative pioneering' period (1788-1900), during which the colonies were being established, saw nature dominated in the national interest, with pastoralism inducing ecological decline and at times collapse (Rolls 1981). The environmental impacts of this period were apparent in what Frawley calls the 'national development and wise use' era (1900-1960s). This was a contradictory time, in which resource exploitation was linked to nation-building but the adverse impacts of Eurocentric development practices had become apparent, prompting both wise use and preservation actions. The former was an early version of science-based sustainable development, aimed at ensuring the longevity of resources such as water, forests, and soils, as well as protecting human health. Preservation was a more romantic realization that saw the founding of national parks and the bushwalking conservation movement, which inspired later environmentalists and the founding of Greens politics (Rainbow 1993a, 1993b).

The 'modern environmentalism' period (1960s-1990s) demonstrated that protection was as worthy a state objective as exploitation. It was not a given, however, but hard won af- 


\section{The Politics of the Environment in Australia}

ter political struggle (Frawley 1994). But environmental protection is not forever, as we have seen, and even where it should be long lasting it can still be under-resourced, endangered, threatened, or revoked. Ironically, the high quality and natural attraction of the Australian environment is generating a new problem in terms of tourism, despite some research efforts in search of sustainable solutions (Hall 1991; Hardy, Beeton, and Pearson 2002). The most obvious impacts of tourism include soil impaction, damage and disturbance to vegetation and plant biodiversity, the intrusion of infrastructure development, and visual and experiential damage, especially in more remote wilderness and World Heritage areas (Pickering and Hill 2007). This is a problem that has intensified with political attitudes to environmental protection that are at times equivocal and at others quite hostile, as well as with governments approving tourism developments even well inside protected World Heritage areas (Legge 2018).

Such issues are well known, as are the shortcomings of governmental processes for environmental management and protection (Dovers and Wild River 2003). There are, however, tenuous links at best between research, evidence-based policy design, effective environmental problem-solving, and political action. There is also much to be learned about the role of federalism in environmental protection, politics, and policy. There is no environmental power in the Australian Constitution, despite the pre-Federation debates about forestry and the management of the Murray River, but the federal government has other ways of intervening in the environmental affairs of the states. It can use its constitutional powers over corporations and exports, for example, or its control over taxation and fiscal distribution to the states, or its obligations under international conventions. However, history shows that federal powers to protect the environment are more likely to be deployed for political rather than environmental gain, if they are deployed at all, and that state decision-making that undermines protection is supported as much as it is opposed.

The environment is not a settled policy domain in Australia. No consistent approaches have seen improvement over time. Part of the difficulty, since the 1990s, has been the bipartisan embrace of neoliberal orthodoxy and the lack of investment in sustainability (Hindess 1998; Miller and Orchard 2014). Neoliberal orthodoxy fails to account for environmental value and the costs of dwindling natural habitat, species loss, population pressures, rising temperatures, and increased climate impacts (SEAC 2016). However, neoliberal orthodoxy can even be set aside in the face of politics, such as when the Abbott Coalition government dismantled carbon pricing, which was cost-efficiently reducing emissions (O'Gorman and Jotzo 2014). The reluctance of Coalition governments to act on climate change (Jericho 2017) and embrace renewable energy is also hurting market growth in the renewables sector, as well as Australia's international standing and its relations in the Asia-Pacific (Crowley and Nakamura 2018). Neoliberalism may run its course (Snow 2017), but statist developmentalism is an enduring settler mindset and would take generations to displace. 


\section{Conclusion}

This chapter points to the struggle by successive generations to manage the Australian environment, and the failed policies and increasingly threatening statist developmentalist processes that remain to be effectively addressed. It identifies Australia's ecological distinctiveness in terms of its vast size, overwhelming aridity, fragile soils, declining remnant vegetation, and disappearing forests and endemic species. Australia's history shows that the practice of statist developmentalism must be addressed, for its ecological failings and for the close relations it fosters between development interests and the state. Remedies include more transparency and accountability in state-developer relations, establishing a national sustainability programme with long-term targets and resources, and devising deliberative forums and other means of accessing civil society views in policy-making. Funding to environmental organizations should be restored on the basis that their campaigning efforts and community-based environmental legal advice counterbalance corporate power and insider influence. New national environmental legislation and associated institutions are well overdue, as is the establishment of a National Sustainability Commission and a National Environment Protection Agency (PYL 2018; Grattan 2018). It is time for more future-oriented political, policy, and institutional approaches to the environment, informed by well-resourced research efforts, that have the capacity to learn from and redress ecological decline.

\section{References}

ABS (Australian Bureau of Statistics) (2009). 'Environmental Views and Behaviour, 200708', https://www.abs.gov.au/Ausstats/abs@.nsf/ 0/85F73AEFDF92C92CCA257AD0000F338B?OpenDocument [accessed 12 Sep. 2019].

ABS (Australian Bureau of Statistics) (2018). 'Statistics by Catalogue Number-No. 46 Environment', http://www.abs.gov.au/AUSSTATS/abs@.nsf/ViewContent? readform\&view $=$ productsbyCatalogue\&Action $=$ Expand $\& N u m=5.1$ accessed 12 Sep. 2019].

ANAO (Australian National Audit Office) (2018). 'National Audit Office-Published Reports', https://www.anao.gov.au/ [accessed 12 Sep. 2019].

Australian Government (2018). 'About Australia', https://www.australia.gov.au/aboutaustralia/ [accessed 12 Sep. 2019].

Birrell, Robert, Hill, Doug, and Stanley, John (eds) (1982). Quarry Australia? Social and Environmental Perspectives on Managing the Nation's Resources. Melbourne: Oxford University Press.

Boardman, Robert (1990). Global Regimes and Nation-States: Environmental Issues in Australian Politics. Ottawa: Carleton University Press. 
Bolton, Geoffrey C. (1992). Spoils \& Spoilers: A History of Australians Shaping their Environment. North Sydney: Allen \& Unwin.

BOM (Bureau of Meteorology) (2019). 'Recent Rainfall, Drought and Southern Australia's long-term rainfall decline', http://www.bom.gov.au/climate/updates/articles/a010southern-rainfall-decline.shtml [accessed 12 Sep. 2019].

Bonyhady, Tim (1993). Places Worth Keeping: Conservationists, Politics, and Law. Sydney: Allen \& Unwin.

Brown, Greg (2019). 'Albanese Visits Queensland Coal Country to Begin Campaign to Win Trust', The Australian, 14 Dec., https://www.theaustralian.com.au/inquirer/albanesevisits-queensland-coal-country-to-begin-campaign-to-win-trust/news-story/ ecb072d5cf6e05480d39c3ac1e88529f [accessed 4 Feb. 2020].

Butlin, Noel G. (1983). 'Trends in Public/Private Relations 1901-1975'. In Brian Head (ed.), State and Economy in Australia, pp. 75-115. Melbourne: Oxford University Press.

Cave, Damien (2019). 'It was supposed to be Australia's Climate Change Election. What Happened?', New York Times, 19 May, https://www.nytimes.com/2019/05/19/world/ australia/election-climate-change.html [accessed 12 Sep. 2019].

Cox, Lisa (2019). 'Campaigners criticise "reckless" approval of Adani mine in Australia', Guardian, 14 Jun., https://www.theguardian.com/environment/2019/jun/14/campaigners-criticise-reckless-approval-adani-mine-australia [accessed 12 Sep. 2019].

Crowley, Kate (2001). 'Effective Environmental Federalism?: Australia's Natural Heritage Trust', Journal of Environmental Policy and Planning 3(4): 255-272.

Crowley, Kate (2010). 'Climate Clever: Kyoto and Australia’s Decade of Recalcitrance'. In Kathryn Harrison and Lisa M. Sundstrom (eds), Global Commons, Domestic Decisions: The Comparative Politics of Climate Change, pp. 201-228. Cambridge, MA: MIT Press.

Crowley, Kate (2013). 'Pricing Carbon: The Politics of Climate Change in Australia', Wiley Interdisciplinary Reviews Climate Change 4(6): 603-613.

Crowley, Kate (2017). 'Up and Down with Climate Politics 2013-2016: The Repeal of Carbon Pricing in Australia', Wiley Interdisciplinary Reviews: Climate Change 8(3): 1-13.

Crowley, Kate and Nakamura, Akihiro (2018). 'Defining Regional Climate Leadership: Learning from Comparative Analysis in the Asia Pacific', Journal of Comparative Policy Analysis 20/4: 387-403.

Crowley, Kate and Walker, Ken J. (eds) (2012). Environmental Policy Failure: The Australian Story. Melbourne: Tilde University Press.

Dovers, Stephen (2000). Environmental History and Policy: Still Settling Australia. Melbourne: Oxford University Press. 
Dovers, Stephen and Wild River, Su (eds) (2003). Managing Australia's Environment. Annandale: Federation Press.

EMC (Essential Media Communications) (2014). 'Essential Report-Importance of Environmental Issues', http://www.essentialvision.com.au/importance-of-environmentalissues [accessed 12 Sep. 2019].

EMC (Essential Media Communications) (2019). 'Essential Report-2019 Election Issues', https://www.essentialvision.com.au/2019-election-issues [accessed 12 Sep. 2019].

FOE (Friends of the Earth Melbourne) (2018). 'Campaigns', https:// www.melbournefoe.org.au/campaigns [accessed 12 Sep. 2019].

Fowler, Robert (2015). 'The Australian Experience with Environmental Federalism: Constitutional and Political Perspectives'. In Kalyani Robbins (ed.), The Law and Policy of Environmental Federalism: A Comparative Perspective, pp. 27-303. Northampton: Edward Elgar.

Frawley, Kevin (1994). 'Evolving Visions: Environmental Management and Nature Conservation in Australia'. In Stephen Dovers (ed.), Australian Environmental History: Essays and Case Studies, pp. 55-78. Melbourne: Oxford University Press

Galvin, Nick (2006). 'We're all Greenies Now', Sydney Morning Herald, 18 Feb., https:// www.smh.com.au/lifestyle/were-all-greenies-now-20060218-gdmzof.html [accessed 12 Sep. 2019].

Gammage, Bill (2012). The Biggest Estate on Earth: How Aborigines Made Australia. Sydney: Allen \& Unwin.

GFN (Global Footprint Network) (2018). 'Ecological Footprint Explorer', http:// data.footprintnetwork.org [accessed 12 Sep. 2019].

Grafton, Quentin, MacDonald, Darla H., Harris, Graham, Bjornlund, Henning, Connor, Jeffery D., Quiggin, John, Williams, John, Crase, Lin, Kingsford, Richard, Wheeler, Sarah A. (2018). 'The Murray Darling Basin Plan is not delivering-there's no more time to waste', The Conversation, 5 Feb., https://theconversation.com/the-murray-darling-basinplan-is-not-delivering-theres-no-more-time-to-waste-91076 [accessed 12 Sep. 2019].

Grattan, Michelle (2018). 'Labor promises a comprehensive overhaul of federal environmental framework', The Conversation, 16 Dec., https://theconversation.com/laborpromises-a-comprehensive-overhaul-of-federal-environmental-framework-108888 [accessed 12 Sep. 2019].

Green, Roger (1984). Battle for the Franklin: Conversations with the Combatants in the Struggle for South West Tasmania. Sydney: Fontana/Australian Conservation Foundation. 


\section{The Politics of the Environment in Australia}

Guest, Chris (2017). Sharing the Water: 100 Years of River Murray Politics. Canberra: Murray Darling Basin Commission.

Hall, Colin M. (1991). Introduction to Tourism in Australia: Impacts, Planning and Development. Melbourne: Longman Cheshire.

Hall, Colin M. (1992). Wasteland to World Heritage. Melbourne: Melbourne University Press.

Hamilton, Clive (2001). Running from the Storm: The Development of Climate Change Policy in Australia. Sydney: University of New South Wales Press.

Hamilton, Clive and Maddison, Sarah (2007). Silencing Dissent: How the Australian Government is Controlling Public Opinion and Stifling Debate. Crows Nest: Allen \& Unwin.

Hardy, Anne, Beeton, Robert J. S., and Pearson, Leonie (2002). 'Sustainable Tourism: An Overview of the Concept and its Position in Relation to Conceptualisations of Tourism', Journal of Sustainable Tourism 10(6): 475-496.

Hepburn, Samantha, (2018). 'Why aren't Australian Laws Preventing Landclearing?', The Conversation, 8 Mar., https://theconversation.com/why-arent-australias-environment-laws-preventing-widespread-land-clearing-92924 [accessed 12 Sep. 2019].

Hindess, Barry (1998). 'Neoliberalism and the National Economy'. In Mitchell Dean and Barry Hindess (eds), Governing Australia: Studies in Contemporary Rationalities of Government, pp. 210-226. Cambridge: Cambridge University Press.

Hoegh-Guldberg, Ove (2016). 'Science, Solutions and the Future: The Great Barrier Reef in a Time of Change', Global Change Institute, https://gci.uq.edu.au/filething/get/195/ GCIQLDPremiersFellowshipReportSummary.pdf [accessed 12 Sep. 2019].

Hunter, Fergus (2018). 'Australia Ranks in Bottom Three Countries for Environmental Policies', Sydney Morning Herald, 18 Sep., https://www.smh.com.au/politics/federal/ australia-ranks-in-bottom-three-rich-countries-for-environmental-policies-20180918-p504ey.html [accessed 12 Sep. 2019].

Irvine, Jessica (2020). 'Environment now Trumps Economy on Australian List of Biggest Worries', Sydney Morning Herald, 22 Jan., https://www.smh.com.au/environment/climate-change/environment-now-trumps-economy-on-australian-list-of-biggestworries-20200121-p53td7.html [accessed 4 Feb. 2020].

Jericho, Greg (2017). 'Flogging the Dead Horse of Neoliberalism isn't going to Improve the Economy', Guardian, 2 Apr., https://www.theguardian.com/business/grogonomics/2017/apr/02/flogging-the-dead-horse-of-neoliberalism-isnt-going-to-improvethe-economy [accessed 12 Sep. 2019]. 
Kilvert, Nick (2019). 'Drought, Climate Change and Mismanagement: What Experts Think Caused the Death of a Million Menindee Fish', ABC Science, 16 Jan., https://

www.abc.net.au/news/science/2019-01-16/what-caused-menindee-fish-killdrought-water-mismanagement/10716080 [accessed 4 Feb. 2020].

Kirkpatrick, James B. (1994). A Continent Transformed: Human Impact on the Natural Vegetation of Australia. Melbourne: Oxford University Press.

Krien, Anna (2012). Into the Woods: The Battle for Tasmania's Forests. Melbourne: Black Inc.

Legge, Kate (2018). 'Open for Business: The Push to Unlock Tasmania's Wilderness', The Australian, 16 Nov., https://www.theaustralian.com.au/weekend-australian-magazine/open-for-business-the-push-to-unlock-australias-wilderness/news-story/ 60712e70a5c0d4b846cba2900a2e8caa [accessed 12 Sep. 2019].

Lindenmayer, David (2007). On Borrowed Time: Australia's Environmental Crisis and What We Must Do About It. Camberwell: Penguin Books.

Lines, William J. (1991). Taming the Great South Land: A History of the Conquest of Nature in Australia. Athens, GA and London: University of Georgia Press.

Lowe, Ian (2005). A Big Fix: Radical Solutions for Australia's Environmental Crisis. Melbourne: Black Inc.

Mathieson, Karl (2014). 'UN rejects Australia's “feeble” bid to strip Tasmanian forest's heritage status', Guardian, 24 Jun., https://www.theguardian.com/environment/2014/ jun/23/un-rejects-australia-tasmanian-forest-heritage [accessed 12 Sep. 2019].

McLeish, Kathy (2017). 'Environmentalists, scientists from the 1960s return to fight for Great Barrier Reef', ABC News, 15 Oct., http://www.abc.net.au/news/2017-10-15/ great-barrier-reef-50-years-on-campaigners-return-ellison-reef/9050106 [accessed 12 Sep. 2019].

Mercer, David and Marden, Peter (2006). 'Ecologically Sustainable Development in a Quarry Economy: One Step Forward, Two Steps Back', Geographical Research 44(2): 183-203.

Merlin, Tracy, Newton, Skye, Ellery, Benjamin, Milverton, Joanne, and Farah, Claude (2015). Systematic Review of the Human Health Effects of Wind Farms. Canberra: National Health and Medical Research Council, https://www.nhmrc.gov.au/sites/default/files/ documents/reports/systematic-review-wind-farms-eh54.pdf [accessed 12 Sep. 2019].

Miller, Chris and Orchard, Lionel (eds) (2014). Australian Public Policy: Progressive Ideas in the Neoliberal Ascendency. Bristol: Policy Press. 
Milman, Oliver (2014). 'Coalition "Taking an Axe” to Environment, Says Mark Butler', Guardian, 7 Feb., https://www.theguardian.com/environment/2014/feb/07/coalitiontaking-an-axe-to-environment-says-mark-butler [accessed 12 Sep. 2019].

Morton, Stephen R., Stafford-Smith, Mark, D., Friedel, Margaret H., Griffin, Graham F., and Pickup, Geoff (1995). 'The Stewardship of Arid Australia: Ecology and Landscape Management', Journal of Environmental Management 43(3): 195-297.

O'Gorman, Marianna and Jotzo, Frank (2014). 'Impact of the Carbon Price on Australia's Electricity Demand, Supply and Emissions'. Crawford School of Public Policy, http:// www.lse.ac.uk/GranthamInstitute/wp-content/uploads/2014/08/OGorman-and-Jotzo-Impact-of-the-carbon-price-on-Australias-electricity-demand-supply-andemissions.pdf [accessed 12 Sep. 2019].

OECD (Organisation for Economic Cooperation and Development) (1998). Environmental Performance Reviews 1998: Australia, Conclusions and Recommendations (Paris: OECD Group on Environmental Performance), http://www.environment.gov.au/resource/ oecd-environmental-performance-reviews-australia [accessed 12 Sep. 2019].

OECD (Organisation for Economic Cooperation and Development) (2008). Environmental Performance Reviews 2007: Australia, Conclusions and Recommendations (Paris: OECD Group on Environmental Performance), http://www.oecd.org/australia/ environmentalperformancereviewsaustralia2008.htm [accessed 12 Sep. 2019].

OECD (Organisation for Economic Cooperation and Development) (2019). Environmental Performance Reviews: Australia 2019 (Paris: OECD Group on Environmental Performance), https://www.oecd.org/australia/oecd-environmental-performance-reviewsaustralia-2019-9789264310452-en.htm [accessed 12 Sep. 2019].

Pearse, Guy (2007). High and Dry: John Howard, Climate Change and the Selling of Australia. Camberwell: Penguin Books.

Pickering, Catherine M. and Hill, Wendy (2007). 'Impacts of recreation and tourism on plant biodiversity and vegetation in protected areas in Australia', Journal of Environmental Management 85(4): 791-800.

Powell, Joseph M. (1978). Environmental Management in Australia, 1788-1914. Guardians, Improvers and Profit: an Introductory Survey. Melbourne: Oxford University Press.

Preece, Noel D. and Van Oosterzee, Penny (2017). 'Australia is a top ten deforester-and Queensland is leading the way', The Conversation, 17 Nov., http://theconversation.com/ australia-is-a-global-top-ten-deforester-and-queensland-is-leading-the-way-87259 [accessed 12 Sep. 2019].

PYL (Places You Love) (2018). 'A New Generation of Nature Laws', https:// www.placesyoulove.org/australiawelove/naturelaws/ [accessed 12 Sep. 2019]. 


\section{The Politics of the Environment in Australia}

Quiggin, John (2017). The Economic (non)viability of the Adani Galilee Basin Project. Submission to the Inquiry into the Governance and operation of the Northern Australia Infrastructure Facility, https://www.aph.gov.au/DocumentStore.ashx? id=32253e7b-3643-4752-8c9e-bf240a44699f\&subId=514377 [accessed 12 Sep. 2019].

Rainbow, Stephen L. (1993a). Green Politics. Auckland: Oxford Press.

Rainbow, Stephen L. (1993b). 'Why did New Zealand \& Tasmania Spawn the World's First Green Parties?', Environmental Politics 1(3): 321-346.

Readfearn, Graham (2018). 'Australia has no climate policy: a quick response to a drawnout farce', Guardian, 21 Aug., https://www.theguardian.com/environment/planet-oz/ 2018/aug/21/australia-has-no-climate-policy-a-quick-response-to-a-drawn-outfarce [accessed 12 Sep. 2019].

Reside, April E., Beher, Jutta, Cosgrove, Anita J., Evans, Megan C., Seabrook, Leonie, Silcock, Jennifer L., Wenger, Amelia S., and Maron, Martin (2017). 'Ecological consequences of land clearing and policy reform in Queensland', Pacific Conservation Biology 23(3): 219-230.

Rolls, Eric C. (1981) A Million Wild Acres: Two Hundred Years of Man and Australian Forest. Melbourne: Nelson Books.

Rootes, Christopher (2008). 'The First Climate Change Election? The Australian General Election of 24 November 2007', Environmental Politics 17(3): 473-480.

SEAC (State of the Environment Advisory Council) (1996). Australia-State of the Environment 1996. Canberra: Department of Environment, Sport and Territories.

SEAC (State of the Environment Advisory Council) (2006). Australia-State of the Environment 2006. Canberra: Department of Environment, Sport and Territories.

SEAC (State of the Environment Advisory Council) (2016). Australia-State of the Environment 2016. Canberra: Department of Environment, Sport and Territories.

Sengupta, Somini, Williams, Jacqueline, and Chandrasekhar, Aruna (2019). 'How One Billionaire Could Keep Three Countries Hooked on Coal for Three Decades', New York Times, 15 Aug., https://www.nytimes.com/2019/08/15/climate/coal-adani-indiaaustralia.html?nytapp=true [accessed 12 Sep. 2019].

Smith, David (1994). Saving a Continent: Towards a Sustainable Future. Sydney: UNSW Press.

Snow, Deborah (2017). 'Paul Keating says neo-liberalism is at "a dead end" after Sally McManus speech', Sydney Morning Herald, 30 Mar., https:/www.smh.com.au/politics/ 


\section{The Politics of the Environment in Australia}

federal/paul-keating-says-neoliberalism-is-at-a-dead-end-after-sally-mcmanusspeech-20170329-gv9cto.html [accessed 12 Sep. 2019].

SSCEC (Senate Standing Committee for Environment and Communications) (2018). Australia's Environment (Canberra: Parliament of Australia), https://www.aph.gov.au/ Parliamentary_Business/Committees/Senate/Environment_and_Communications/ Ausenviron/Report [accessed 12 Sep. 2019].

Stewart, Donald and McColl, Greg (1994). 'The Resource Assessment Commission: An Inside Assessment', Australian Journal of Environmental Management 1(1): 12-23.

Talberg, Anita, Hui, Simeon, and Loynes, Kate (2016). Australian Climate Change Policy to 2015: A Chronology, Parliamentary Library Research Paper Series 2015-16, Canberra: Australian Parliament.

Taylor, Lenore (2015). 'Green "lawfare": voters feel Coalition is trying to silence environment groups', Guardian, 10 Sep., http://www.theguardian.com/australia-news/2015/ sep/10/green-lawfare-voters-feel-coalition-is-trying-to-silence-environmentgroups [accessed 12 Sep. 2019].

Taylor, Maria (2014). Global Warming and Climate Change: What Australia knew and buried...then framed a new reality for the public. Canberra: ANU Press.

Thwaites, John and Kestin, Tahl (2018). 'Australia Ranked Worst in the World on Climate Action', The Conversation, 13 Jul., https://reneweconomy.com.au/australia-rankedworst-world-climate-action-49472/ [accessed 12 Sep. 2019].

Toyne, Phillip (1994). The Reluctant Nation: Environment, Politics \& the Law in Australia. Sydney: ABC Books.

UNESCO (United Nations Educational, Scientific and Cultural Organisation) (2018). 'Australia-UNESCO World Heritage Centre', https://whc.unesco.org/en/statesparties/au [accessed 12 Sep. 2019].

Walker, Ken J. (1999). 'Statist Developmentalism in Australia'. In Ken J. Walker and Kate Crowley (eds), Australian Environmental Policy 2: Studies in Decline \& Devolution, pp. 22-44. Sydney: UNSW Press.

Walker, Ken J. (2011). 'Australia's Construction of Environmental Policy'. In Kate Crowley and Ken J. Walker (eds), Environmental Policy Failure: The Australian Story, pp. 11-28. Melbourne: Tilde University Press.

Walker, Ken J. and Crowley, Kate (eds) (1999). Australian Environmental Policy: Studies in Decline \& Devolution. Sydney: UNSW Press.

Warhurst, John (2007). 'The Howard Decade in Australian Government and Politics', Australian Journal of Political Science 42(2): 189-194. 
Webb, Leonard J., Whitelock, Derek, and Brereton, John L. G. (1969). The Last of the Lands. Milton: Jacaranda Press.

White, Sue (2009). 'Our Top Ten Environmental Problems'. ABC News, 7 Dec., http:// www.abc.net.au/environment/articles/2009/12/07/2764044.htm [accessed 12 Sep. 2019].

Wright, Judith (1977). Coral Battleground. Melbourne: Spinifex Press.

WWF (World Wildlife Fund for Nature) (2018). 'Backyard Barometer Report: Australian Attitudes to Nature', http://www.wwf.org.au/knowledge-centre/resource-library/resources/backyard-barometer\#gs.6EKEIFo [accessed 12 Sep. 2019].

Yencken, David and Wilkinson, Debra (2000) Resetting the Compass: Australia's Journey Towards Sustainability. Collingwood: CSIRO Publishing.

\section{Notes:}

(1.) The measure takes into account greenhouse gas emissions within Australia, emissions embodied in the goods Australians consume, climate change vulnerability, and exported emissions from fossil fuel shipments to other countries (Thwaites and Kestin 2018).

(2.) See, for example, the work of Environmental Justice Australia (https:// www.envirojustice.org.au/) and of David Schlosberg (https://www.youtube.com/watch? $\mathrm{v}=$ bswgdWJ3QR8).

\section{Kate Crowley}

University of Tasmania, Department of Politics and Policy 